Special issue of the 3rd International Conference on Computational and Experimental Science and Engineering (ICCESEN 2016)

\title{
Iron and Aluminium Removal from Algerian Silica Sand by Acid Leaching
}

\author{
S. Anas BoussaA ${ }^{a, b, *}$, A. Kheloufi $^{a}$, N. Boutarek ZaOurar ${ }^{b}$ And S. Bouachma ${ }^{a}$ \\ ${ }^{a}$ Division croissance cristalline et procédés métallurgiques CCPM Centre de recherche en technologie des \\ semi-conducteurs pour l'énergétique (C.R.T.S.E), 02 Bd Frantz Fanon BP. 140 Alger 7 merveilles, \\ Alger 16200, Algérie \\ ${ }^{b}$ Laboratoire des technologies des matériaux, USTHB, B.P. 32 El Alia, Bab Ezzouar, Alger, 16111 Algérie
}

This work refers to a process of purification of silica sand and, more particularly, to a process of iron and aluminium removal from the Algerian silica sand particles. Iron compounds are among the most difficult impurities to release from the sand particles. Several methods to remove iron from the sand particles are used; in our work we employed the acid leaching process as optimal solution to purify the silica sand. To this purpose, our work began by characterization of sand samples using X-ray fluorescence, for measurement of concentrations of major mineral oxides, and using atomic absorption, to determine the iron and aluminium concentrations in the silica sand particles. Through this study, the samples were enriched by acid leaching method, by removing the impurities from the crystal lattice, as well as from its surface. Thus reduction the impurities concentration increases, at the same time, the $\mathrm{SiO}_{2}$ concentration. The obtained enriched silica can be used as raw material for silicon production, destined for photovoltaic application.

DOI: 10.12693/APhysPolA.132.1082

PACS/topics: 88.40.jj

\section{Introduction}

Silica raw material is usually used in such applications as foundry sand, ceramics, sandblasting and other abrasive applications, in water filtration, pigments, hydraulic fracturing and propping in the oil industry [1].

High purity material is used as a high-tech raw material for optical fibers, electro-magnetic materials, and catalysis materials, as well as in silicon production for photovoltaic application [2].

The photovoltaic (PV) devices convert the Sun energy directly into the electrical energy [3, 4]. The production of silicon for photovoltaic application by carboreduction of silica is an industrial process [5] used since the beginning of the 20th century. The silicon produced using this method contains many undesirable impurities. Various techniques were developed about thirty years ago to purify silicon. These techniques are very expensive and generally cause important losses of material [6]. To avoid those losses, to reduce the cost of silicon and to improve its purity for photovoltaic application, there are attempts to purify silica raw materials using low cost and efficient techniques, to reduce the cost of silicon.

Iron is one of the most troublesome impurities in silica sand because it impairs the transparency of high-quality glass, e.g. for tableware, and optical glass; it impairs transmission in optical fibers; it adversely affects the production of pure silicon products, e.g. silicon metal for photovoltaic application, silicon carbide [7].

*corresponding author; e-mail: sabiha.anas@gmail.com
One of the main tasks in the purification of silica sand is to further reduce iron compounds to a required level by a highly efficient method.

Several investigations were carried out in this field, using various techniques. Magnetic separation, froth flotation, selective flocculation, and chemical and biological leaching are some of the commonly practiced techniques for the removal of ferric iron oxides or hydroxides in the silica raw materials. However, physical separation techniques, such as flotation or magnetic separation, are generally less effective for iron removal than chemical leaching, aiming at dissolving iron compounds bonded to the surface or existing as distinct mineral grains [8]. Some of the previous work and results in these field are presented in Table I.

To date in the published literature, generally the particle size of sand was fixed before the leaching process. In our study we use the sand with its natural grain size. Thus we avoid the crushing operation and save valuable time and money and reduce the losses of sand raw material.

The aim of this project is to examine the high effectiveness of several acids, in removing iron and aluminium impurities from from Chlef quartz sand, by a simple leaching method.

\section{Materials and methods}

\subsection{Silica sand samples}

The silica sand in these experiments was purchased from Chlef sand, Algeria.

The chemical composition of the silica sand sample used in this study was determined before leaching, using XRF analysis. The results are presented in Table II. 
Studied sand consists mainly of $\alpha$-quartz and feldspar with small quantities of rutile, anatase, muscovite, microcline, magnetite and biotite.
Table III represents the concentration of these elements before leaching.

Summary of experimental work on iron removal from silica raw material.

\begin{tabular}{|c|c|c|c|c|}
\hline $\begin{array}{c}\text { Amount } \\
\text { of } \mathrm{Fe}_{2} \mathrm{O}_{3} \\
\text { in silica raw } \\
\text { material }\end{array}$ & $\begin{array}{l}\text { Leaching } \\
\text { reagent }\end{array}$ & Other considered parameters & Iron removal yield [\%] & Ref. \\
\hline $\begin{array}{l}0.18 \\
\text { (silica sand) }\end{array}$ & $\begin{array}{l}\text { Powerful } \\
\text { ultrasonic }\end{array}$ & $\begin{array}{l}\text { The treatment time, chemical reagent, } \\
\text { electrolytes powerful ultrasonic }\end{array}$ & 49 & [9] \\
\hline $\begin{array}{l}0.213 \\
\text { (silica sand) }\end{array}$ & $\begin{array}{l}\text { Reverse } \\
\text { flotation }\end{array}$ & $\begin{array}{l}\text { Type and concentration of collec- } \\
\text { tors, type of acid, pH, conditioning } \\
\text { time, solid-in-pulp concentration, par- } \\
\text { ticle size and temperature }\end{array}$ & up to 90 & {$[10]$} \\
\hline $\begin{array}{l}1.5 \\
\text { (silica sand) }\end{array}$ & $\mathrm{HF}$ and $\mathrm{HCl}$ & $\begin{array}{l}\text { Concentrations of the leaching agents, } \\
\text { time, leaching temperature, and } \\
\text { with/without } \mathrm{H}_{2} \mathrm{O}_{2}\end{array}$ & 98.5 & [11] \\
\hline $\begin{array}{l}0.29 \% \\
\text { (silica sand) }\end{array}$ & $\begin{array}{l}\text { Biological ba- } \\
\text { sin treatment }\end{array}$ & $\begin{array}{l}\text { Changes of climate temperature, using } \\
\text { fresh surface water without disin- } \\
\text { fection, inhibition of algae and fungi, } \\
\text { and promoting bacteria }\end{array}$ & up to 70.5 & {$[12]$} \\
\hline $\begin{array}{l}0.06 \\
\text { (silica sand) }\end{array}$ & Oxalic acid & $\begin{array}{l}\text { The reaction temperature, stirring } \\
\text { speed, ultrasound power, acid concen- } \\
\text { tration and reaction time }\end{array}$ & 75.4 & [13] \\
\hline $\begin{array}{l}850 \mathrm{ppm} \\
\text { (silica sand) }\end{array}$ & $\begin{array}{l}\mathrm{HF}, \mathrm{HCl} \\
\text { and } \mathrm{H}_{2} \mathrm{SO}_{4}\end{array}$ & $\begin{array}{l}\text { Concentrations of the leaching agents, } \\
\text { time }\end{array}$ & - & [14] \\
\hline $\begin{array}{l}0.0481 \% \\
\text { (silica sand) }\end{array}$ & $\begin{array}{l}\text { Phosphoric } \\
\text { acid }\left(\mathrm{H}_{3} \mathrm{PO}_{4}\right)\end{array}$ & $\begin{array}{l}\text { Concentrations of the leaching agents, } \\
\text { leaching temperature, particle sizes } \\
\text { of quartz sand, s/l mass ratio, and } \\
\text { with/without ultrasound irradiation }\end{array}$ & up to 81 & [15] \\
\hline $\begin{array}{l}0.089 \\
\text { (silica sand) }\end{array}$ & Oxalic acid & $\begin{array}{l}\text { Acid concentration, stirring rate, tem- } \\
\text { perature, leaching duration }\end{array}$ & $\begin{array}{l}\text { results revealed that the leaching effi- } \\
\text { ciency for such extremely fine silica sand } \\
\text { decreased with increasing stirring speed }\end{array}$ & {$[16]$} \\
\hline $\begin{array}{l}1.46 \\
\text { (quartz silica) }\end{array}$ & $\begin{array}{l}\text { Magnetic } \\
\text { separation }\end{array}$ & Effect of particle size & up to 62 & {$[17]$} \\
\hline $\begin{array}{l}0.62 \\
\text { (silica } \\
\text { sandstone) }\end{array}$ & $\begin{array}{l}\text { Hydrochloric } \\
\text { acid }\end{array}$ & Magnetic separation, a leaching process & up to 83 & [18] \\
\hline $\begin{array}{l}0.325 \\
\text { (silica sand) }\end{array}$ & Water & Mechanical milling & up to 22 & [19] \\
\hline
\end{tabular}

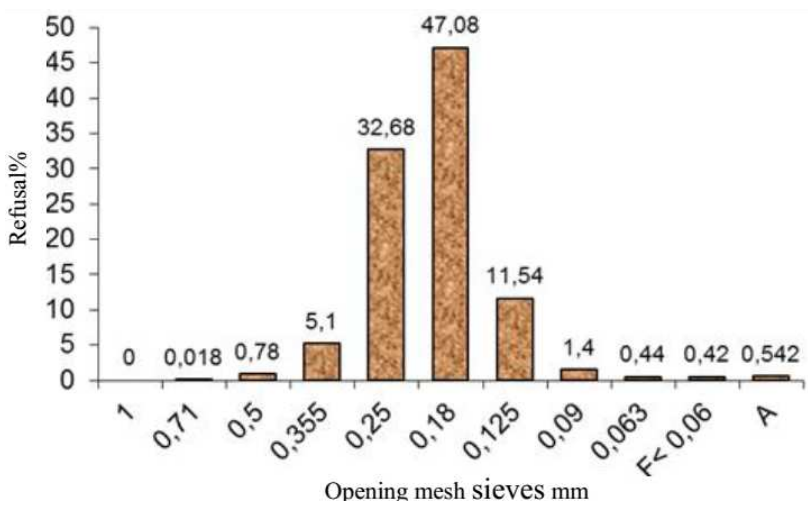

Fig. 1. Histogram representation of granulometric analysis of Chlef sand.
TABLE II

Chemical analysis of dry silica sand

\begin{tabular}{c|c|c|c|c|c|c|c|c|c|c}
\hline \hline $\begin{array}{c}\text { Elem. } \\
\mathrm{SiO}_{2}\end{array}$ & $\mathrm{Al}_{2} \mathrm{O}_{3}$ & $\mathrm{Fe}_{2} \mathrm{O}_{3}$ & $\mathrm{CaO}$ & $\mathrm{MgO}$ & $\mathrm{Na}_{2} \mathrm{O}$ & $\mathrm{K}_{2} \mathrm{O}$ & $\mathrm{TiO}_{2}$ & $\mathrm{MnO}$ & $\mathrm{P}_{2} \mathrm{O}_{5}$ \\
\hline $\begin{array}{c}\text { Conc. } \\
\text { [\%] }\end{array}$ & 96.92 & 1.12. & 1.56 & 0.15 & 0.14 & $<0.05$ & 0.11 & 0.13 & $<0.05$ & $<0.05$
\end{tabular}

\section{TABLE III}

Concentration of iron and aluminium before leaching.

\begin{tabular}{c|c}
\hline \hline \% Fe before leaching & \% Al before leaching \\
\hline 0.59 & 0.26
\end{tabular}

The particle size was ascertained by means of sieving. The results are shown in Fig. 1. 
As it is indicated in Fig. 1 the studied sand sample has a particle size distribution within a narrow size range, with $91 \%$ being in the $0.25-0.125 \mathrm{~mm}$ fraction.

\subsection{Reagents}

Several acids were used, such as $\mathrm{HF}, \mathrm{H}_{3} \mathrm{PO}_{4}, \mathrm{H}_{2} \mathrm{C}_{2} \mathrm{O}_{4}$, $\mathrm{HNO}_{3}$ and $\mathrm{H}_{2} \mathrm{SO}_{4}$, to investigate mainly there effect on the iron and aluminium removal. $\mathrm{NaOH}$ and distilled water were used throughout this work.

The hydrofluoric acid (HF) was chosen for its chemical compatibility with silica (highly hydrophobic). Its role as a solvent in the leaching process is double: the first one is to purify or to extract impurities from silica, in this context HF is well known for its efficiency; the second one is to etch silica grains for reducing their size, this fact improves the output of leaching, especially in our work, because we use the sand with its natural grain sizes. The second acid processing by $\mathrm{H}_{3} \mathrm{PO}_{4}, \mathrm{H}_{2} \mathrm{C}_{2} \mathrm{O}_{4}, \mathrm{HNO}_{3}$ or $\mathrm{H}_{2} \mathrm{SO}_{4}$ is intended to remove the residual impurities (Fe and $\mathrm{Al}$ ) in solution. Finally, this acid processing is followed by an alkaline attrition, using a solution with $10 \%$ of sodium hydroxide $(\mathrm{NaOH})$, in order to eliminate the residual impurities from the sand quartz surface.

Considering the ecological impact of acid solutions, the waste acid solutions of leaching steps were collected, neutralized with lime and transferred to acid regeneration units of recycling laboratories.

\subsection{Leaching tests}

For the first part of the experiment, $200 \mathrm{~g}$ of Chlef dry sand have been processed by $400 \mathrm{ml}$ of hydrofluoric acid $(20 \%)$ in a Heidolph rotator eluter, for ten minutes, at ambient temperature. For the second part of experiment, all leaching tests were conducted in a $250 \mathrm{ml}$ glass beaker placed on a heater, with a magnetic stirrer having a controller unit. When the required temperature $\left(100^{\circ} \mathrm{C}\right)$ of the beaker contents (100 $\mathrm{ml}$ of acid) was reached, approximately $25.0 \mathrm{~g}$ of dry sand were added into the beaker, while the contents of the beaker has been stirred at a constant speed of $600 \mathrm{rpm}$. The beaker was covered to prevent losses by evaporation. From leaching solution, an amount of sample of the reaction mixture was taken out at pre-determined time intervals, filtered, repeatedly washed with distilled water to remove any unspent acid, and then dried at $120^{\circ} \mathrm{C}$ for $2 \mathrm{~h}$. All experiments were carried out in duplicate and sometimes repeated again, and the mean values are reported.

The leachate was examined by atomic absorption spectroscopy (Varian-AA240) in order to measure the concentration of $\mathrm{Fe}$ and $\mathrm{Al}$.

\section{Results and discussion}

\subsection{Effects of different types of acids on leaching efficiency of iron and aluminium impurities}

The influence of acids on the percentage of iron and aluminium removal was examined using solutions with concentrations of $20 \%$ of acids at $100^{\circ} \mathrm{C}$ stirred at $600 \mathrm{rpm}$.
The results are shown in Figs. 2-5. Two points can be observed immediately, one is that the percentages of iron in Chlef sand have decreased remarkably during first two hours, but have increased during the next half hour.

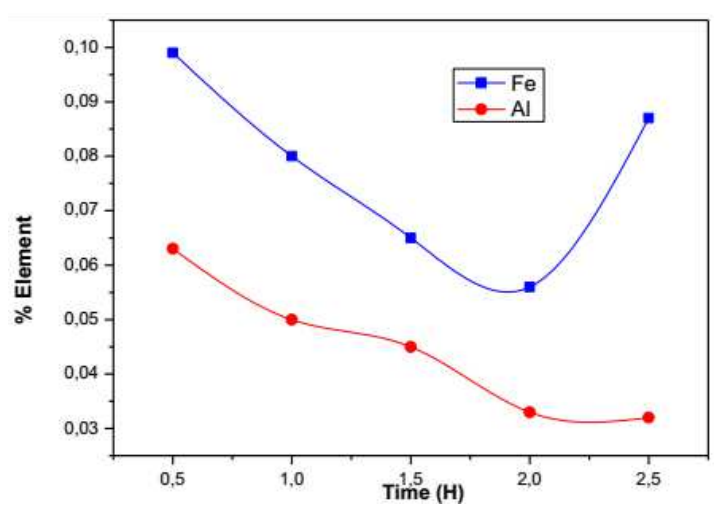

Fig. 2. Effect of $\mathrm{HNO}_{3}$ acid on percentages of iron and aluminium in Chlef sand.

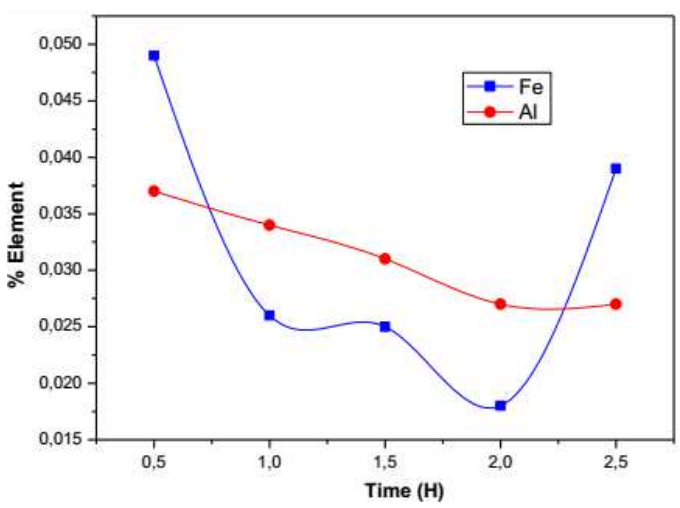

Fig. 3. Effect of $\mathrm{H}_{2} \mathrm{C}_{2} \mathrm{O}_{4}$ acid on percentages of iron and aluminium in Chlef sand.

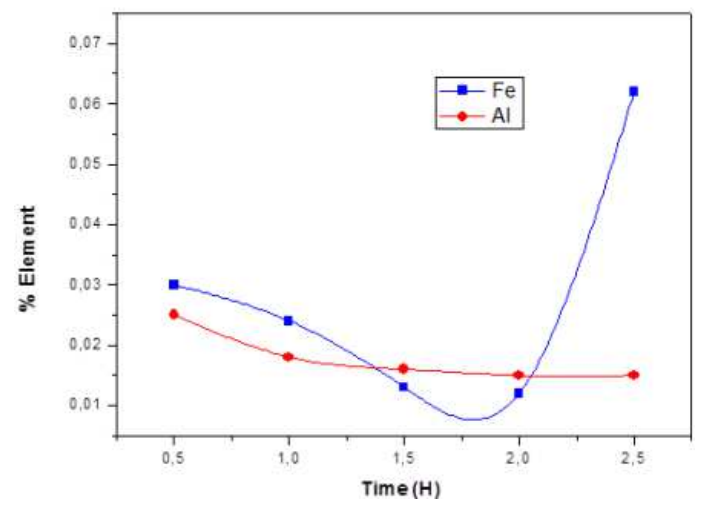

Fig. 4. Effect of $\mathrm{H}_{2} \mathrm{SO}_{4}$ acid on percentages of iron and aluminium in Chlef sand.

The same remark is true for aluminium leaching, however after two hours the concentration of aluminium remained stable.

The possible reason for these two distinct rates is explained as follows: in the initial phase of the leaching, 


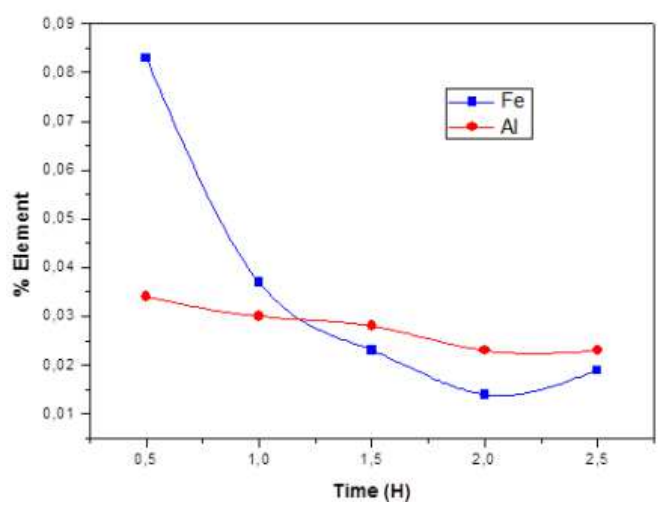

Fig. 5. Effect of $\mathrm{H}_{3} \mathrm{PO}_{4}$ acid on percentages of iron and aluminum in Chlef sand.

iron hydroxyl-oxides which are possibly located on the surface of the silica sand grains have been leaching out. During the second phase of the leaching, iron oxides which are possibly located on the surface of silica sand grains react slowly with the acid. In other words, it is easier to dissolve hydroxyl-oxides, such as goethite, where dissolution can take place via both reduction (solid and aqueous species) and complexation, whereas oxides, such as hematite, dissolve mainly via solid reduction [12].

At $100^{\circ} \mathrm{C}$, after two hours of acid leaching, the amount of maximum removal of iron and aluminium is represented in Table IV.

TABLE IV

Maximum concentration of removed iron and aluminium.

\begin{tabular}{c|c|c}
\hline \hline Acid & $\begin{array}{c}\text { Maximum conc. } \\
\text { of removed iron } \\
{[\%]}\end{array}$ & $\begin{array}{c}\text { Maximum conc. } \\
\text { of removed aluminium } \\
{[\%]}\end{array}$ \\
\hline $\mathrm{H}_{2} \mathrm{SO}_{4}$ & 97.96 & 94.23 \\
$\mathrm{H}_{3} \mathrm{PO}_{4}$ & 97.62 & 91.15 \\
$\mathrm{H}_{2} \mathrm{C}_{2} \mathrm{O}_{4}$ & 96.94 & 89.61 \\
$\mathrm{HNO}_{3}$ & 90.5 & 87.3
\end{tabular}

\subsection{Scanning electron microscopy analysis}

Figure 6 shows the scanning electron microscope images of the silica sand before the leaching process.

Figure 7 shows the leached solid samples, prepared at a reaction temperature of $100^{\circ} \mathrm{C}$ for 2 hours. The presence of mineral coatings on the silica sand particles is shown in Fig. 6. The main iron and aluminium impurities are bonded to the mineral coatings. The surface coatings of the solid sample become thinner after leaching at conventional stirring speed of $600 \mathrm{rpm}$ in acid solutions (Fig. 7).

\section{Conclusions}

Our experiments have verified that the sulfuric acid is one of the best leaching agents for the removal of iron

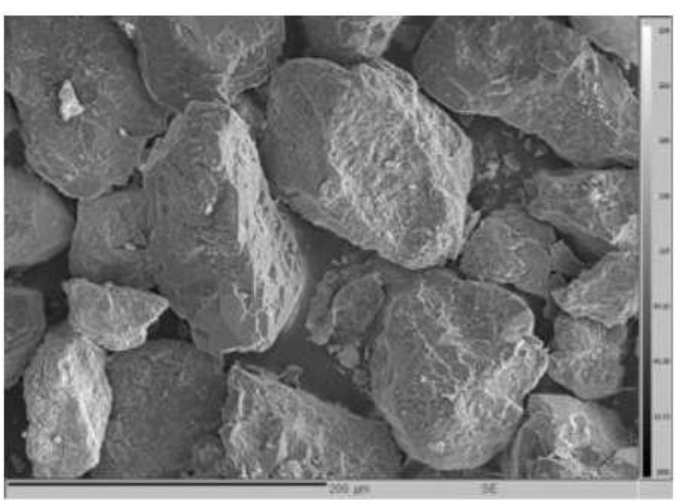

Fig. 6. Scanning electron micrograph of Chlef sand before leaching test.

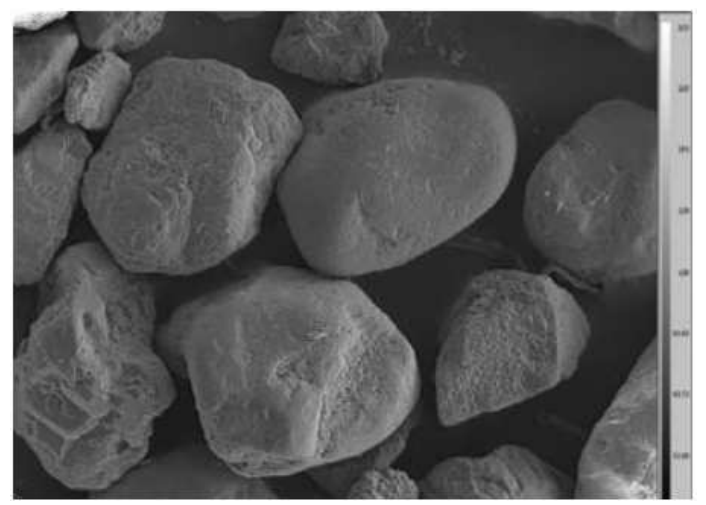

Fig. 7. Scanning electron micrograph of Chlef sand after leaching test.

and aluminium impurities from the quartz sand, due the properties of $\mathrm{H}_{2} \mathrm{SO}_{4}$.

The optimal leaching rates for iron and aluminium are up to $97.9 \%$ and $94.2 \%$, respectively, after $120 \mathrm{~min}$, in the conditions of temperature of $100{ }^{\circ} \mathrm{C}$, ratio of solid to liquid of $25 \%$, and quartz sand grain size of $0.25-$ $0.125 \mathrm{~mm}$.

We conclude that Chlef sand, after its enrichment, has got good proprieties for production of metallurgical grade silicon for photovoltaic applications by the briquetting process [20].

\section{Acknowledgments}

This work was completed thanks to the National Funds of Research, DGRSDT/MESRS (Algeria).

\section{References}

[1] S. Anas Boussaa, A. Kheloufi, N. Boutarek Zaourar, F. Kerkar, Acta Phys. Pol. A 129, 133 (2016).

[2] Houquan Huang, Jingsheng Li, Xiaoxia Li, Zhizhen Zhang, Separat. Purificat. Technol. 108, 45 (2013).

[3] O.M. Pişirir, O. Bingöl, Acta Phys. Pol. A 130, 36 (2016). 
[4] B. Kirişa, O. Bingöl, R. Şenol, A. Altintaş, Acta Phys Pol. A 130, 55 (2016).

[5] S. Anas Boussaa, A. Kheloufi, N. Boutarek Zaourar, A. Kefaifi, F. Kerkar, AIP Conf. Proc. 1758, 030043 (2016).

[6] M. Khalifa, M. Hajji, H. Ezzaouia, EPJ Web Conf. 29, 00014 (2012).

[7] F. Veglio, B. Passariello, M. Barbaro, P. Plescia, A.M. Marabini, Int. J. Miner. Process. 54, 183 (1998).

[8] A. Tuncuk, S. Ciftlik, A. Akcil, Hydrometallurgy 134-135, 80 (2013)

[9] H.L. Zhao, D.X. Wang, Y.X. Cai, F.C. Zhang, Minerals Engin. 20, 816 (2007).

[10] D. Mowla, G. Karimi, K. Ostadnezha, Separat. Purificat. Technol. 58, 419 (2008).

[11] A. Kheloufi, Chem. Engin. Trans. 17, 711 (2009).

[12] I. Štyriaková, K. Jablonovská, A. Mockovčiaková, A. Bekéniyová, I. Štyriak, I. Kraus, M. Osacký, M. Lovás, Hydrometallurgy 104, 443 (2010).
[13] Feihu Du, Jingsheng Li, Xiaoxia Li, Zhizhen Zhang, Ultrasonics Sonochem. 18, 389 (2011).

[14] A. Kheloufi, Y. Berbar, A. Kefaifi, S. Medjahed, F. Kerkar, Chem. Engin. Trans. 24, 1513 (2011).

[15] Zhizhen Zhang, Jingsheng Li, Xiaoxia Li, Houquan Huang, Lifen Zhou, Tiantian Xiong, Int. J. Mineral Proc. 114-117, 30 (2012).

[16] Houquan Huang, Jingsheng Li, Xiaoxia Li, Zhizhen Zhang, Separat. Purificat. Technol. 108, 45 (2013).

[17] A. Kheloufi, M. Fathi, H. Rahab, A. Kefaifi, A. Keffous, S.A. Medjahed, Chem. Engin. Trans. 32, 889 (2013).

[18] S. Bouabdallah, M. Bounouala, A.S. Chaib, Mining Sci. 22, 33 (2015)

[19] H. Nazratulhuda, M. Othman, IOP Conf. Series: Mater. Sci. Engin. 114, 012114 (2016).

[20] S. Pizzini, Method for preparing high purity metallurgical grade silicon, Brevet 2011. 